\title{
Casting of Clad Strip by a Vertical Type Twin Roll Caster
}

\author{
Toshio Haga $^{1, *}$, Hisaki Watari ${ }^{2}$ \\ ${ }^{1}$ Department of Mechanical Engineering, Osaka Institute of Technology, Japan \\ ${ }^{2}$ Tokyo Denki University, Japan
}

Copyright $(\mathcal{C} 2015$ by authors, all rights reserved. Authors agree that this article remains permanently open access under the terms of the Creative Commons Attribution License 4.0 International License

\begin{abstract}
A sound three-layer clad strip of 4045, 3003, and 4045 was cast by a vertical type tandem twin roll caster. However, a sound three-layer clad strip of 5182, 3003, and 5182 could not be cast. The 5182 overlay strip did not bond to the 3003 base strip. The latent heat of Si and $\mathrm{Mg}$ are 1787 $\mathrm{kJ} / \mathrm{kg}$ and $230 \mathrm{~kJ} / \mathrm{kg}$, respectively. The latent heat affected the rise in temperature of the base strip. The 3003 was not heated up to a temperature suitable for bonding with the 5182 overlay strip. A sound two-layer clad strip of 3003 and 5182 could be cast by a twin roll caster equipped with a scraper. The temperature of the 3003 was near the solidus line, and sound bonding occurred.
\end{abstract}

Keywords Clad Strip, Twin Roll Caster, Bonding, Bonding Interface, Continuous Casting

\section{Introduction}

The fabrication of clad strips requires multiple processes and consumes a significant amount of energy. The strip is made from a slab by surface scraping, heat treatment, hot rolling and cold rolling. The strips are cleaned, the edges of the strips are welded, and the strips are connected by hot rolling. Therefore, a process- and energy-saving method is required. Recently, "Fusion Technology" has been developed that produces clad material by direct chill (DC) casting $[1,2]$. If the strip could be made directly from the molten metal, energy would be saved. A twin roll caster can cast a strip directly from molten metal by one process. The twin roll caster has an advantage in terms of both process savings and energy savings. A conventional twin roll caster for aluminum alloy has a disadvantage in that the casting speed is very low (typically less than $5 \mathrm{~m} / \mathrm{min}$ )[3-8]. A vertical type high-speed twin roll caster was proposed to improve the casting speed [9-11]. The roll speed of the vertical type high-speed twin roll caster (VHSTRC) ranges from 30 $\mathrm{m} / \mathrm{min}$ to $150 \mathrm{~m} / \mathrm{min}$. The adaption of the vertical type twin roll caster for the fabrication of clad strips was attempted in order to attain both process and energy savings. Two kinds of twin roll casters for clad strips were devised. One is a vertical type tandem twin roll caster (VTTRC), and the other is a vertical type twin roll caster equipped with a scraper
(VTRCS) [12-15]. The former can cast three-layer clad strip, and the latter can cast two-layer of clad strip.

Aluminum alloy clad strips can be cast by these twin roll casters; however, the relationship between the casting conditions, the aluminum alloys used, and the bonding of the strips has not been investigated. During the fabrication of the clad strips by hot rolling, bonding of a 5182 aluminum alloy strip to another aluminum alloy strip is reported to be very difficult due to surface oxidation of the 5182 strip caused by the $\mathrm{Mg}$ alloying element. It is possible that oxidation of the 5182 strip negatively impacts bonding during the fabrication of the clad strip using a twin roll caster. Casting of a clad strip consisting of the 3003 and 5182 aluminum alloys has been carried out to investigate the influence of the $\mathrm{Mg}$. On the other hand, fabrication of a clad strip of the 3003 and 4045 aluminum alloys via hot rolling is reported to be straightforward. Casting of a clad strip of consisting of the 3003 and 4045 aluminum alloys has also been investigated by our group.

In this study, clad strips of 3003 and 4045, 3003 and 5182 aluminum were cast to investigate the relationship between the casting conditions, the aluminum alloys used, and the bonding of the strips. The difference in the bonding conditions between the 3003 and 4045 clad strips and between the 3003 and 4045 clad strips is discussed.

\section{Twin roll caster}

Vertical type tandem twin roll caster. A schematic illustration and a photograph of the VTTRC is shown in Fig. $1[13,14]$. One VHSTRC is mounted on the other VHSTRC. Three-layer of clad strip can be cast by the VTTRC. A base strip is cast by the upper twin roll caster, and the overlay strips are cast by the lower twin roll caster. The roll speeds of the upper and lower twin roll casters are set to be the same. The upper and lower twin roll casters are rotated at a designated roll speed before pouring the molten metal. The molten metal for the base strip is poured first. The base strip is led into the gap between the rolls of the lower twin roll caster, and after that, the molten metal for the overlay strips is poured. The roll gap of the lower twin roll caster is set wider than the thickness of the base strip. The combination of alloys for the base strip and the overlay strip is selected such that the solidification temperature of the base strip is higher than that of the overlay strip to prevent heating of the 
base strip to a semisolid condition. The roll loads of the upper and lower twin roll casters are much lower than those of a conventional twin roll caster for aluminum alloy (CTRA). In the process of the present study, bonding of the strips by hot rolling is not intended. Parting material is not used because the strip does not stick to the roll since it is a copper roll. The parting material adheres to the strip. The adhered parting material on the base strip makes the contact condition between the base strip and the molten metal of the overlay strips worse. Thus, it is preferable not to use parting material for the cladding. The thickness of the strip can be controlled by the roll speed and the solidification length. The clad ratio can be controlled by the solidification length.

Twin roll caster equipped with a scraper. Schematic illustrations of the VTRCS and an enlarged view of the scraper are shown in Fig. 2 [15]. Two-layer of clad strip can be cast by the VTRCS. The effects of the scraper are as follows. The aluminum alloy, which has a higher solidification temperature than the other alloy, is cast into a strip using the scraper. The scraper can be rotated around a fulcrum and is pushed at a constant load. The scraper scribes the semisolid layer on the free solidified surface. The free solidified surface becomes flat, and the thickness becomes uniform. Mixture of the two molten metals is prevented. The scribed strip does not contact the atmosphere before contacting the molten metal of the other alloy. The molten metal of the scribed surface is poured first, and then the molten metal of the other alloy is poured. Copper rolls are used, and the roll load is much lower than in a CTRA. The thickness is controlled by the roll speed and the solidification length. The clad ratio is controlled by the solidification length. The scraper is made from a 3.2-mm-thick plate of mild steel, and this plate is covered by a 2-mm-thick insulator sheet. The $\mathrm{BN}$ is sprayed as a parting material on the insulator sheet. The insulator sheet is useful to prevent a reaction between the mild steel plate and the molten metal. Moreover, the insulator sheet is useful to prevent a reduction in temperature of the molten metal.
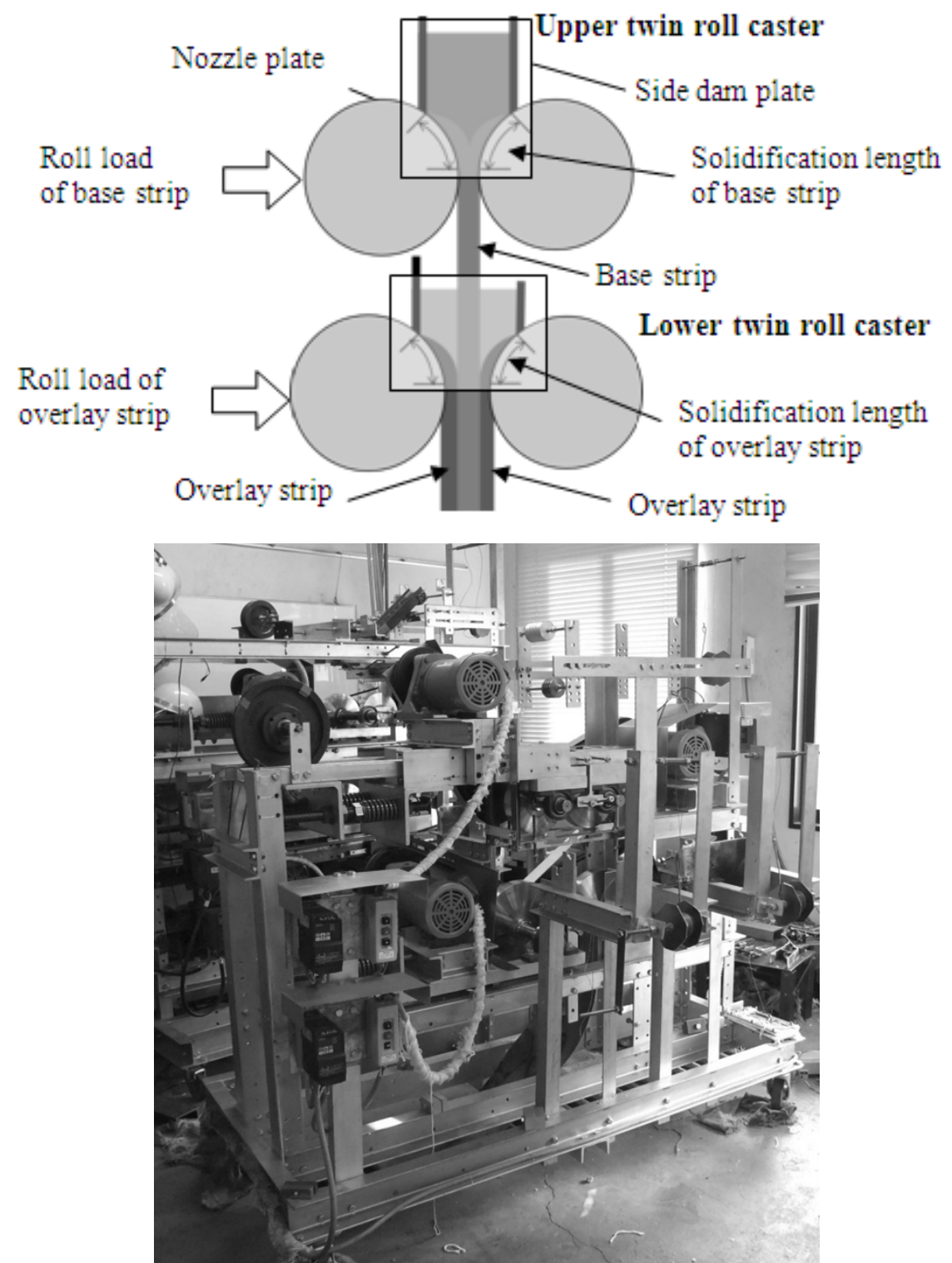

Figure 1. Schematic matic illustration and photograph showing a vertical type tandem twin roll caster 

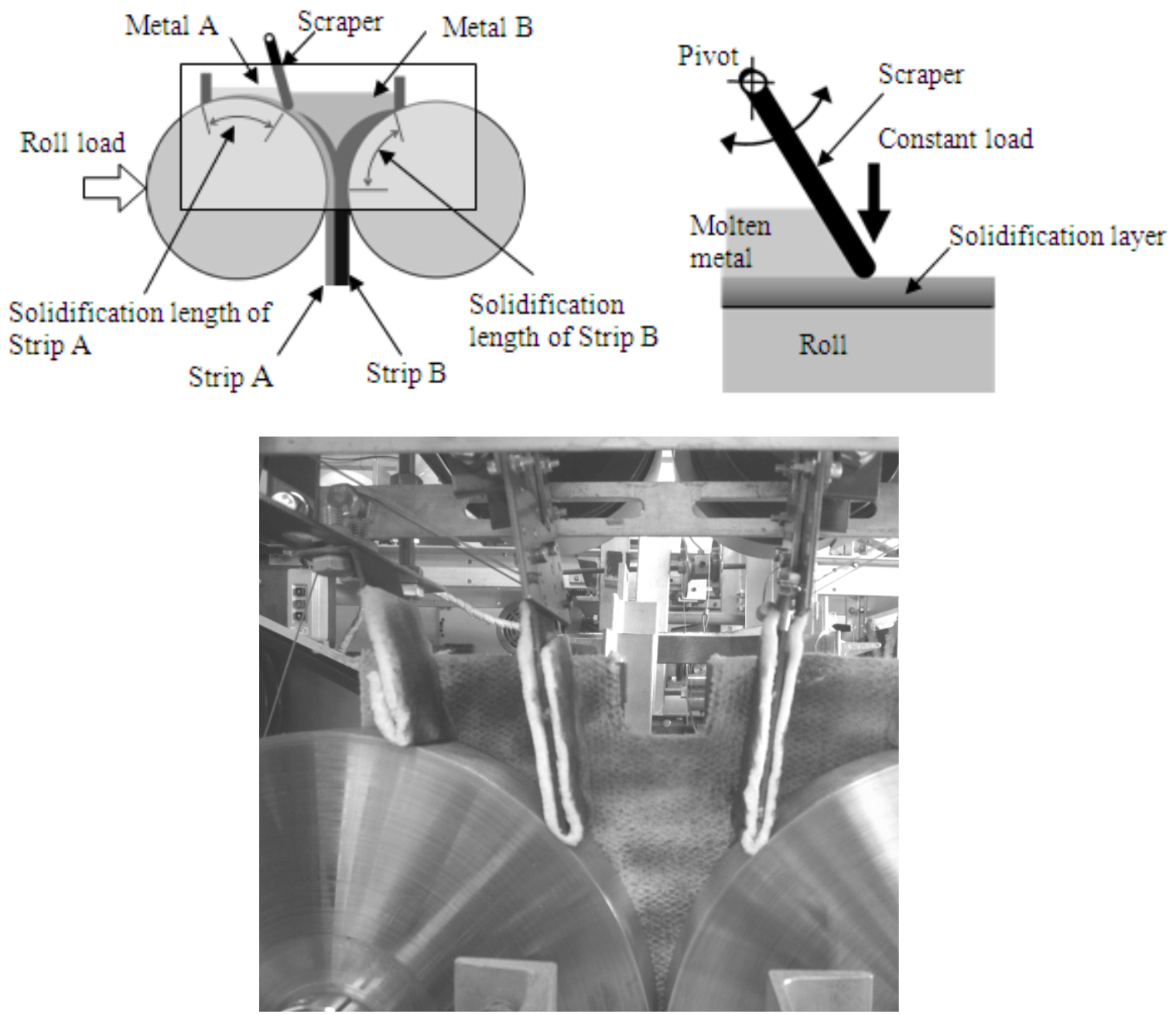

Figure 2. Schematic illustration and photograph of a vertical type twin roll caster equipped with a scraper.

\section{Experimental Conditions}

Three-layer clad strip. Two kinds of three-layer clad strips were cast. In the type A clad strip shown in Table 1, the base strip was 3003 , and the overlay strip was 4045 . The cladding of the 4045 strip to other aluminum alloys by hot rolling is not difficult. It is said that the fabrication of a clad strip consisting of Al-Mg alloy and another aluminum alloy by hot rolling is difficult. Therefore, 5182 was used as the overlay strip in the type B clad strip shown in Table 2. The influences of the pouring temperature of the overlay strip and the roll load of the lower twin roll caster on the cladding were investigated. In the type B clad strip, cladding was not sufficient. Therefore, the effect of the solidification temperature of the base strip on the cladding was investigated. $\mathrm{Mg}$ was added to the 3003 to lower the solidification temperature.
Table 1. Casting conditions for three-layer clad strip consisting of 4045,3003 and 4045 (Type A)

\begin{tabular}{|c|c|c|}
\hline \multirow{5}{*}{$\begin{array}{c}\text { Upper twin roll } \\
\text { caster } \\
\text { (Base strip) }\end{array}$} & material & 3003 \\
\hline & $\begin{array}{c}\text { Pouring temperature } \\
\left({ }^{\circ} \mathrm{C}\right)\end{array}$ & 670 \\
\hline & Roll load (kN) & $2.2,8.8$ \\
\hline & Roll size (mm) & $\begin{array}{c}\text { Diameter : } 300 \text {, width : } \\
40\end{array}$ \\
\hline & $\begin{array}{c}\text { Solidification length } \\
(\mathrm{mm})\end{array}$ & 60 \\
\hline \multirow{5}{*}{$\begin{array}{l}\text { Lower twin roll } \\
\text { caster } \\
\text { (Overlay strip) }\end{array}$} & material & 4045 \\
\hline & $\begin{array}{c}\text { Pouring temperature } \\
\left({ }^{\circ} \mathrm{C}\right)\end{array}$ & 610,700 \\
\hline & Roll load $\quad(k N)$ & $0.5,1.1,8.8$ \\
\hline & Roll size $(\mathrm{mm})$ & $\begin{array}{c}\text { Diameter :300, width : } \\
42\end{array}$ \\
\hline & $\begin{array}{c}\text { Solidification length } \\
(\mathrm{mm})\end{array}$ & 80 \\
\hline \multicolumn{2}{|c|}{ Roll speed (m/min) } & $20,30,40$ \\
\hline
\end{tabular}


Table 2. Casting conditions for three-layer clad strip consisting of 5182,3003 and 5182 (Type B)

\begin{tabular}{|c|c|c|}
\hline \multirow{5}{*}{$\begin{array}{l}\text { Upper twin roll } \\
\text { caster } \\
\text { (Base strip) }\end{array}$} & material & $\begin{array}{c}3003,3003+1 \% \mathrm{Mg} \\
3003+2.5 \% \mathrm{Mg}\end{array}$ \\
\hline & $\begin{array}{l}\text { Pouring temperature } \\
\left({ }^{\circ} \mathrm{C}\right)\end{array}$ & 670 \\
\hline & Roll load $(\mathrm{kN})$ & 2.2 \\
\hline & Roll size $(\mathrm{mm})$ & Diameter : 300, width : 40 \\
\hline & $\begin{array}{c}\text { Solidification length } \\
(\mathrm{mm})\end{array}$ & 100 \\
\hline \multirow{5}{*}{$\begin{array}{l}\text { Lower twin roll } \\
\text { caster } \\
\text { (Overlay strip) }\end{array}$} & material & 5182 \\
\hline & $\begin{array}{l}\text { Pouring temperature } \\
\left({ }^{\circ} \mathrm{C}\right)\end{array}$ & 650,700 \\
\hline & Roll load & 8.8 \\
\hline & Roll size $(\mathrm{mm})$ & Diameter : 300 , width : 42 \\
\hline & $\begin{array}{l}\text { Solidification length } \\
(\mathrm{mm})\end{array}$ & 100 \\
\hline \multicolumn{2}{|c|}{ Roll speed (m/min) } & 30 \\
\hline
\end{tabular}

Two-layer clad strip. A two-layer clad strip consisting of 3003 and 5182 was cast under the following conditions. A 3003 strip was cast by the roll equipped with a scraper since the solidification temperature of 3003 is higher than that of 5182. The gap between the scraper and the roll was set to 1 $\mathrm{mm}$ before pouring the molten metal to prevent the strip from sticking to the scraper. The scraper was not pre-heated. The roll was rotated at a designated speed before pouring the molten metal. The molten 3003 metal was poured first, and then the molten 5182 metal was poured. The experimental conditions are shown in Table 3 . The solidus and liquidus line temperatures of the alloys are shown in Table 4. The chemical compositions of the alloys are shown in Table 5.

Table 3. Casting conditions for two-layer clad strip consisting of 3003 and 5182

\begin{tabular}{|c|c|c|}
\hline \multirow{4}{*}{$\begin{array}{l}\text { Scribed strip } \\
\text { (Base strip) }\end{array}$} & material & 3003 \\
\hline & $\begin{array}{c}\text { Pouring temperature } \\
\left({ }^{\circ} \mathrm{C}\right)\end{array}$ & 670 \\
\hline & Scraper load $(\mathrm{N})$ & 20 \\
\hline & $\begin{array}{c}\text { Solidification length } \\
(\mathrm{mm})\end{array}$ & 100 \\
\hline \multirow{3}{*}{$\begin{array}{l}\text { No-scribed strip } \\
\text { (Overlay strip) }\end{array}$} & material & 5182 \\
\hline & $\begin{array}{l}\text { Pouring temperature } \\
\left({ }^{\circ} \mathrm{C}\right)\end{array}$ & 650 \\
\hline & $\begin{array}{l}\text { Solidification length } \\
(\mathrm{mm})\end{array}$ & 100 \\
\hline \multicolumn{2}{|c|}{ Roll speed (m/min) } & 20 \\
\hline \multicolumn{2}{|c|}{ Roll size (mm) } & Diameter :300, width :40 \\
\hline \multicolumn{2}{|c|}{ Roll load (kN) } & 4.4 \\
\hline
\end{tabular}

Table 4. Solidus line and liquidus line temperature

\begin{tabular}{|c|c|c|c|}
\hline Solidification temperature & 3033 & 4045 & 5182 \\
\hline Liqudus line temperature $\left({ }^{0} \mathrm{C}\right)$ & 654 & 590 & 638 \\
\hline Solidus line temperature $\left({ }^{0} \mathrm{C}\right)$ & 643 & 577 & 577 \\
\hline
\end{tabular}

Table 5. Chemical compositions of the aluminium alloys (mass $\%$ )

\begin{tabular}{|c|c|c|c|c|c|c|c|}
\hline Alloy & $\mathrm{Si}$ & $\mathrm{Fe}$ & $\mathrm{Cu}$ & $\mathrm{Mn}$ & $\mathrm{Mg}$ & $\mathrm{Zn}$ & $\mathrm{Al}$ \\
\hline 3003(Al-Mn) & 0.25 & 0.62 & 0.14 & 1.16 & 0.01 & 0.01 & bal \\
\hline $4045(\mathrm{Al}-\mathrm{Si})$ & 9.86 & 0.17 & 0.01 & 0.01 & 0.01 & 0.02 & bal \\
\hline $5182(\mathrm{Al}-\mathrm{Mg})$ & 0.05 & 0.14 & 0.11 & 0.42 & 4.75 & 0.01 & bal \\
\hline
\end{tabular}

Bonding condition. The bonding condition was investigated by observation of the interface and a continuous bending test. The continuous bending test was conducted as a simple test to investigate the bonding condition. The strip was continuously bent until broken, and the broken area was observed using an optical microscope. The continuous bending test is shown in Fig. 3.

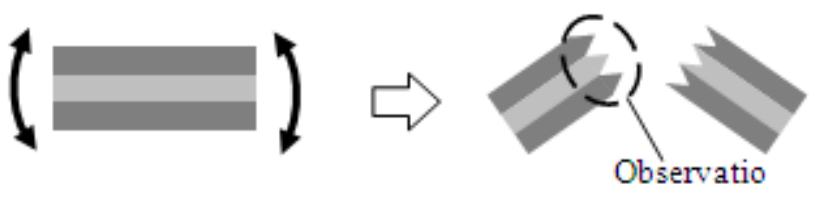

Figure 3. Schematic illustration of the continuous bending test

\section{Result and Discussion}

Three layer-clad strip of 4045,3003 and 4045 . The effect of the roll speed on the bonding was investigated. The as-cast strip was cold rolled down to $2 \mathrm{~mm}$, and a continuous bending test was conducted. The cold rolled strips peel at the interface if the bonding force is low. Therefore, cold rolling was conducted before the continuous bending test. The pouring temperature $\left(700^{\circ} \mathrm{C}\right)$ for the 4045 overlay strip was higher than the liquidus line temperature of the 3003 base strip. The bonding time between the 3003 base strip and the 4045 overlay at the roll bite decreases as the roll speed increases. On the other hand, the temperature of the 3003 base strip at the roll bite increases as the roll speed increases. It is thought that a longer bonding time and a higher base strip temperature are better since they increase the temperature of the base strip to a suitable temperature for bonding. The results of the continuous bending test are shown in Fig. 4. Under these experimental conditions, the roll speed did not affect the bonding. The solidus line temperature of the 3003 base strip is higher than the liquidus and solidus line temperatures of 4045 . The 4045 was solidified at the interface. This means that the temperature of the 3003 base strip was lower than the solidus line temperature of the 4045 overlay strip when the clad strip was released from the roll. The temperature of the 3003 base strip was within the temperature range suitable for bonding at roll speeds ranging from $20 \mathrm{~m} / \mathrm{min}$ to $40 \mathrm{~m} / \mathrm{min}$.

The effect of the roll load of the upper twin roll caster on the bonding was investigated. The roll load of the upper twin roll caster influences the temperature of the 3003 base strip. The temperature of the 3003 decreases as the roll load increases. The pouring temperature for the 4045 overlay strip was $610^{\circ} \mathrm{C}$, and this temperature was lower than the solidus line temperature of the 3003 base strip. The results of the continuous bending test of the clad strip, which was cold rolled down to $2 \mathrm{~mm}$, are shown in Fig. 5. Peeling did not occur at the interface. The roll load of the upper twin roll caster did not affect the bonding. This shows that sound cladding occurs when the pouring temperature and the liquidus line temperature of the overlay strip are lower than the solidus line temperature of the base strip. 


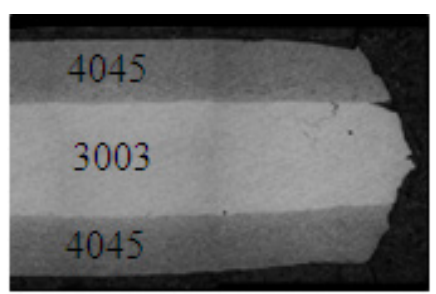

(a) $20 \mathrm{~m} / \mathrm{min}$

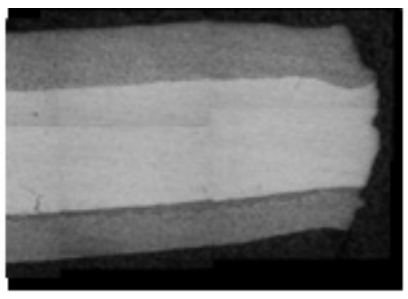

(b) $30 \mathrm{~m} / \mathrm{min}$

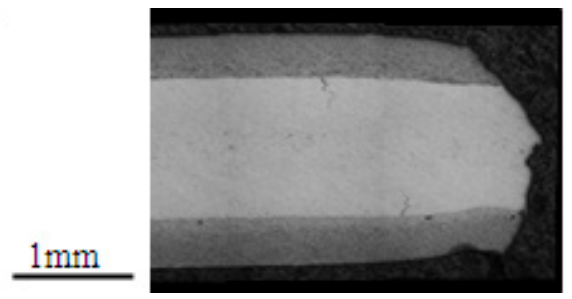

(c) $40 \mathrm{~m} / \mathrm{min}$

Figure 4. Results of the continuous bending test conducted to investigate the influence of the roll speed on the bonding. The roll-load of the upper twin roll caster was $2.2 \mathrm{kN}$, and that of the lower twin roll caster was $1.1 \mathrm{kN}$. The pouring temperature of the 4045 was $700^{\circ} \mathrm{C}$.

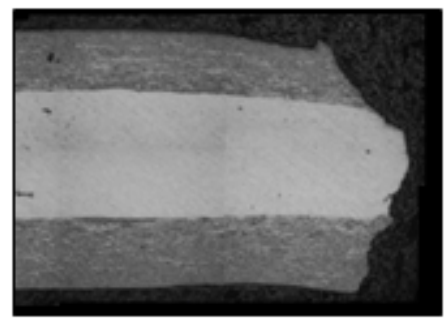

(a) $2.2 \mathrm{kN}$

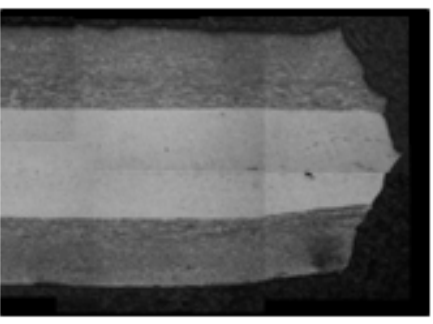

(b) $8.8 \mathrm{kN}$

Figure 5. Results of the continuous bending test conducted to investigatet the influence of the roll load of the upper twin roll caster. The pouring temperature of the 4045 overlay strip was $610^{\circ} \mathrm{C}$, the roll load of the lower twin roll caster was $1.1 \mathrm{kN}$, and the roll speed was $20 \mathrm{~m} / \mathrm{min}$.

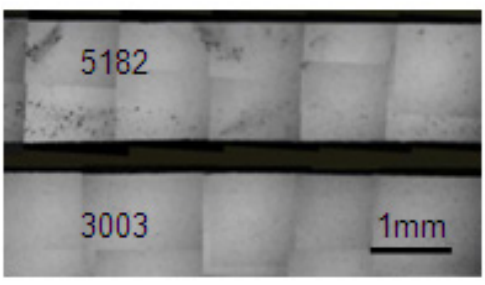

(a) $5182: 650^{\circ} \mathrm{C}$

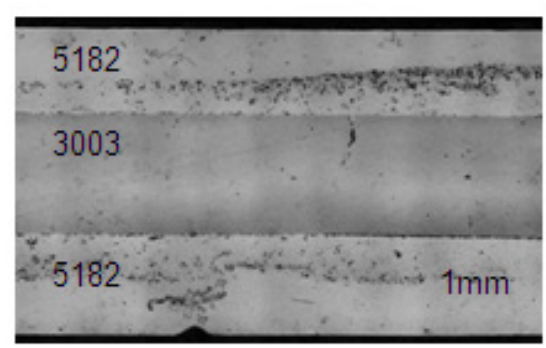

(b) $5182: 700^{\circ} \mathrm{C}$

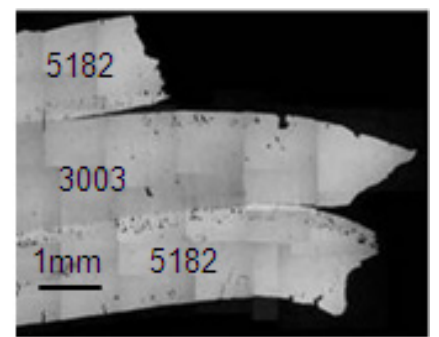

(c) result of bending test of (b)

Figure 6. Cross sections of as-cast three-layer clad strip showing the effect of the pouring temperature of 5182, and the result of the bending test: (a) the 5182 overlay strip was not bonded to the 3003 base strip, (b) cross section of three layer-clad strip, (c) broken area of (b) from continuous bending test.

Three layer-clad strip of 5182, 3003 and 5182. The effect of the pouring temperature for the 5182 overlay strip was investigated. A continuous bending test was conducted on the as-cast strip. The cross section of the as-cast clad strip and the result of the continuous bending test are shown in Fig. 6 . The 5182 overlay strip was not bonded to the 3003 base strip when the pouring temperature was $650^{\circ} \mathrm{C}$. When the pouring temperature was $700^{\circ} \mathrm{C}$, the 5182 bonded to the 3003 . However, the 5182 was easily peeled from the 3003 in the continuous bending test. Thus, the bonding force was very weak. The pouring temperature for the 5182 overlay strip affected the bonding. It became clear that a higher pouring temperature may be required for bonding a clad strip consisting of the 3003 and 5182 aluminum alloys. The temperature of the 3003 base strip was increased as the temperature of the 5182 molten metal increased. The temperature of the 3003 base strip influences the bonding.

It is thought that unsound bonding occurred due to the oxidation of the $\mathrm{Mg}$ included in the 5182 or because the 3003 base strip was not heated to a suitable temperature for bonding with the 5182 overlay strip. $\mathrm{Mg}$ was added to the 3003 base strip to investigate the cause of the unsound cladding. The addition of $\mathrm{Mg}$ to the 3003 base strip lowers the solidification temperature. We believe that lowering the solidification temperature of the base strip lowers the temperature suitable for bonding.

On the other hand, oxidation of the base strip becomes remarkable by adding $\mathrm{Mg}$ to the 3003 base strip, and the bonding condition may become worse. The cross section of the clad strips using a 3003 base strip with added $\mathrm{Mg}$ is shown in Fig. 7. The 5182 overlay strip was bonded to the 3003 base strip with added Mg. This result means that the bonding condition improved by the lowering the solidification temperature of the base strip. The effect of the oxidation of the strips on the cladding might be smaller than the lowering of the required temperature for the bonding of the base strip. 


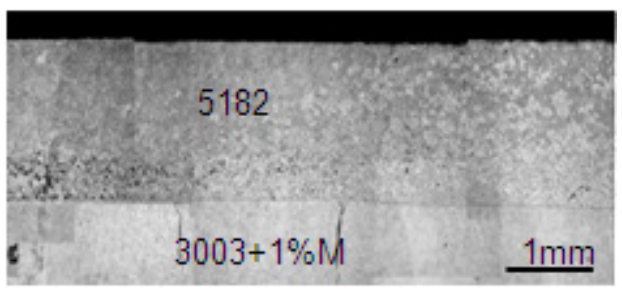

(a) base strip: $1 \% \mathrm{Mg}$ added 3003

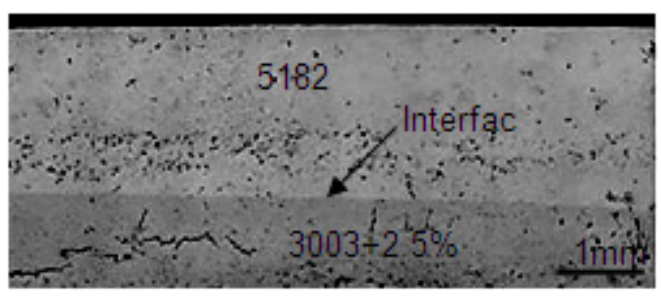

(b) base strip: $2.5 \% \mathrm{Mg}$ added 3003

Figure 7. Effect of the addition of $\mathrm{Mg}$ to the 3003 base strip on the bonding.

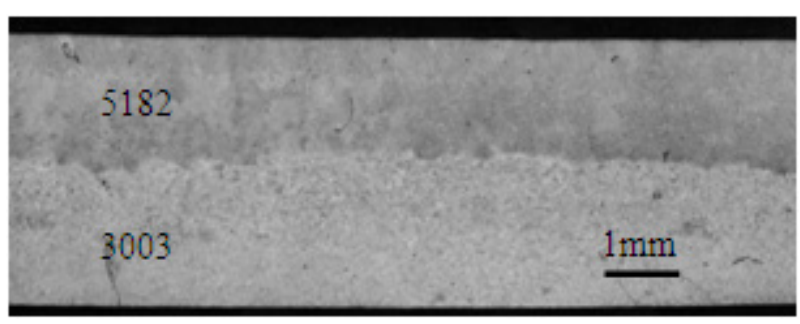

(a) as-cast strip

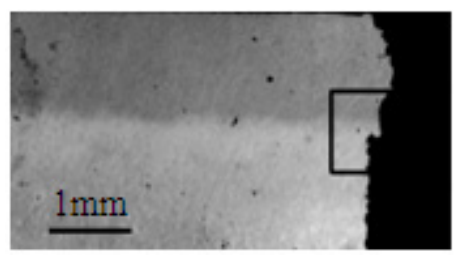

(b) result of bending test of (a)

Figure 8. Cross section of as-cast clad strip cast by the twin roll caster equipped with a scraper and the result of the continuous bending test

Two-layer clad strip of $\mathbf{3 0 0 3}$ and $\mathbf{5 1 8 2}$. Cross sections of the as-cast strip and continuously bent strip (until failure) are shown in Fig. 8. Sound cladding was attained by the VTRCS, as shown in Fig. 8. Peeling did not occur in the continuous bending test. The 5182 strip was strongly bonded to the 3003 strip. The molten metal of the 5182 contacted the scribed surface of the 3003. The temperature of the scribed 3003 strip might be higher than the solidus line temperature of the 5182. However, the scribed surface of the 3003 strip was suitable for bonding. The temperature of the 3003 strip was cooled by the roll to the suitable temperature for bonding before it reached the roll bite.

Difference between 4045 and 5182. The 4045 strip was bonded to the 3003 strip by the VTTRC. However, the 5182 strip was not bonded to the 3003 by the VTTRC. The liquidus line temperature of 5182 is higher than that of 4045 , as shown in Table 4 . The release of latent heat in 5182 begins at a higher temperature than in 4045 . This is suitable for the increasing temperature of the base strip. It is thought from the above results that the pouring temperature and the liquidus line temperature of the overlay strip did not significantly affect bonding. Attention is paid to the latent heat of $\mathrm{Si}$ and $\mathrm{Mg}$. The latent heat of $\mathrm{Si}$ is $1787 \mathrm{~kJ} / \mathrm{kg}$, and that of $\mathrm{Mg}$ is $230 \mathrm{~kJ} / \mathrm{kg}$. The latent heat of $\mathrm{Si}$ is about eight times larger than that of $\mathrm{Mg}$. The latent heat of the 4045 is higher than that of the 5182. Therefore, the 4045 could increase the temperature of the 3003 base strip to a temperature suitable for bonding, but the 5182 could not increase the temperature of the 3003 base strip. The VTRCS can control the temperature of the 3003 strip near the solidus line temperature at the start of contact with the molten 5182 metal through the use of the scraper. The temperature of the 3003 strip was cooled by the roll to the suitable temperature for bonding before it reached the roll bite. The temperature of the 3003 strip is high enough to allow bonding to the 5182 alloy without additional heating. Strips of material with a small latent heat like the 5182 alloy can be bonded to a 3003 strip. In this regard, the VTRCS is excellent.

\section{Conclusions}

The fabrication of clad strips was attempted using a VTTRC and a VTRCS. The dominant factor affecting bonding was the temperature of the strip that solidifies first. While the 5182 strip did not bond to the 3003 strip using the VTTRC, the 4045 strip bonded to the 3003 strip. The latent heat of $\mathrm{Si}$ is about eight times larger than that of $\mathrm{Mg}$. The latent heat of the strip that solidifies second affects the increase in temperature of the strip that solidifies first. Specifically, the 4045 strip (solidifies second) increased the temperature of the 3003 base strip (solidifies first) to that suitable for bonding, while the 5182 strip (solidifies second) did not. In that regard, the VTRCS was useful for maintaining the temperature of the strip that solidified first at a suitable temperature for bonding, and was able to successfully bond the 5182 strip to the 3003 strip. The key advantage of these processes is that the negative influence of the $\mathrm{Mg}$ on bonding was negligible.

\section{Acknowledgements}

This work was supported by KAKENHI (Grant-in-Aid for Scientific Research (C) 15K00607).

\section{REFERENCES}

[1] R.B.Wagstaff, D.J.Lioyd, T.F.Bishoff, "Direct Chill Casting of Clad Ingot", Material Science Forum, 
519-521(2006),1809-1814.

[2] R.Wagstaff, T.Bishoff, D.Siden, "Downstream Considerations of Fusion Clad casting", Material Science Forum, 630(2010),175-178.

[3] R.Cook, P.G.Groock, P.M.Thomas, D.V.Edmonds, J.D.Hunt, Development of the twin-roll casting process, J.Mater.Process.Technol., 55(1995)76-84.

[4] B.Taraglio, C.Romanowski, Thin-gage/high-speed roll casting technology for foil production, Light Met (1995)1165-1182.

[5] A.I.Nussbaum, Three-state-of-the-art Thin -gage high-speed roll caster for aluminum alloy sheet products PartIII, Light Met Age, 55(1997)34-39.

[6] O.Daland, A.B.Espedal, M.L.Nedreberg, I.Alvestad, Thin gage twin-roll casting, process capabilities and product quality, Light Met. (1997)745-752.

[7] S.Hamers, D.Smith, C.Romanowski, G.Yildizbayrak, B.Taraglio, Twin roll casting of aluminum at $2.5 \mathrm{~mm}$ gauge. Production experience and process improvement, Light Met,
(1999)931-937.

[8] M.Duendar, OE.Keles, B.Kerti, N.Dogan, Crystallographic texture development of twin-roll cast aluminum strips, Light Met, (2004)723-724.

[9] T.Haga, H.Watari, S.Kumai: Archives of Materials Science and Engineering, 15(2006),p.186.

[10] T.Haga, M.Ikawa, H.Watari, S.Kumai: ibid. 17(2006),p.337.

[11] T.Haga, M.Ikawa, H.Watari, S.Kumai: ibid. 18(2007),p.7.

[12] T.Haga, M.Matsuo, D.Kunigo, H.Hatanaka,S.Kumai: J.Achievements Materials \& Manufacturing Engineering, 37(2009),p172.

[13] Haga:ibid, 43(2010) 393-402.

[14] T.Haga, R.Nakamura, S.Kumai and H.Watari: Archives of Materials Science and Engineering, 37(2009),p117.

[15] T.Haga, K.Akitsu, K.Kamakura, S.Kumai, H.Watari: J.Achievements Materials \& Manufacturing Engineering, 55(2012),p26. 